\title{
STUDI FENOMENOLOGI PENGGUNAAN E-MODUL DALAM PEMBELAJARAN DARING MUATAN IPA DI SD MUHAMMADIYAH 5 JAKARTA
}

\author{
Indri Dwiyanti ${ }^{1}$, A.R. Supriatna ${ }^{2}$, Arita Marini ${ }^{3}$ \\ 1,2, 3PGSD FIP Universitas Negeri Jakarta \\ 1indridwiyanti16@gmail.com, ${ }^{2}$ arsupriatna@unj.ac.id, ${ }^{3}$ Arita250268@yahoo.co.id
}

\begin{abstract}
ABSTRACK
The aim of this study is to describe the implementation of E-modules utilization in online learning of natural science content at SD Muhammadiyah 5 Jakarta. This research was conducted at SD Muhammadiyah 5 Jakarta. The subjects of this study are fifth grade students of SD Muhammadiyah 5 Jakarta. The approach used in this research is qualitative approach with phenomenological methods. Data collection was through observation, interview, and documentation with the data analysis technique used was the Miles and Huberman model. The results showed that the implementation of E-modules in online learning of natural science content in class $\checkmark$ SD Muhammadiyah 5 Jakarta as an effective learning resource and support the students at learning, that helps during online learning, stimulating students and motivating students to learn, and achieving learning goals. The e-module is a webbased module which contains material with pictures, videos and edugames that make learning more engaging for students. The application of E-module received positive responses from various parties, that is students, parents, and outsiders such as other schools.
\end{abstract}

Keywords: E-module use, online learning, natural science content

\begin{abstract}
ABSTRAK
Penelitian ini bertujuan untuk mendeskripsikan pelaksanaan penggunaan $E$-modul dalam pembelajaran daring muatan IPA di SD Muhammadiyah 5 Jakarta. Penelitian ini dilaksanakan di SD Muhammadiyah 5 Jakarta. Subjek penelitian ini terdiri dari siswa kelas V SD Muhammadiyah 5 Jakarta. Pendekatan yang digunakan dalam penelitian adalah pendekatan kualitatif dengan metode fenomenologi. Pengumpulan data dilakukan dengan cara observasi/pengamatan, wawancara, dan dokumentasi dengan teknik analisis data yang digunakan adalah model Miles dan Huberman. Hasil penelitian menunjukkan bahwa penggunaan E-modul dalam pembelajaran daring muatan IPA di kelas V SD Muhammadiyah 5 Jakarta sebagai sumber belajar efektif dan membantu siswa dalam belajar yaitu membantu selama pembelajaran daring, meransang siswa serta memberi motivasi belajar kepada siswa, dan tercapainya tujuan pembelajaran. E-modul tersebut merupakan E-modul berbasis web yang memuat materi disertai gambar, video dan edugame yang membuat pembelajaran semakin menarik bagi siswa. Penggunaan E-modul tersebut mendapatkan respon positif dari berbagai pihak yaitu siswa, orang tua, dan pihak luar seperti sekolah lain.
\end{abstract}

Kata kunci: Penggunaan E-modul, pembelajaran daring, muatan IPA 


\section{A. Pendahuluan}

Pendidikan merupakan usaha sadar untuk

mewujudkan pembelajaran agar peserta didik aktif dalam mengembangkan potensi dirinya, serta menjadi manusia yang beriman dan bertakwa kepada Tuhan yang Maha Esa, berakhlak mulia, sehat, berilmu, cakap, kreatif, mandiri, dan menjadi warga negara yang demokratis serta bertanggung jawab. Pendidikan terdiri dari pendidikan formal dan nonformal. Pendidikan sekolah dasar merupakan salah satu contoh dari pendidikan formal yang memiliki peranan penting. Ketika peserta didik menempuh pendidikan di sekolah dasar, peserta didik berada dalam masa golden age. Oleh karena itu, pelaksanaan pendidikan di Sekolah Dasar hendaknya sesuai dengan tujuan pendidikan sekolah dasar yang tercantum dalam pasal 13 Undang-undang Nomor 20 Tahun 2003 bahwa pendidikan dasar diselenggarakan untuk mengembangkan sikap dan kemampuan serta memberikan pengetahuan dan keterampilan dasar yang diperlukan untuk hidup dalam masyarakat serta mempersiapkan peserta didik yang memenuhi persyaratan untuk mengikuti pendidikan menengah. IImu Pengetahuan Alam merupakan salah satu muatan pelajaran yang terdapat di sekoah dasar. Pada kurikulum 2013, muatan IPA di kelas I, II, dan III diintegrasikan kedalam muatan pelajaran lainnya. Sedangkan di kelas IV, V, dan VI nama muatan pelajaran IPA tercantum dan memiliki Kompetensi Dasar.

Indonesia saat ini, sedang dilanda wabah covid-19. Wabah covid-19 tersebut semakin berkepanjangan dan memberikan dampak yang besar dalam aspek kehidupan manusia. Ekonomi, sosial, dan pendidikan tidak luput terkena dampak Covid-19. Salah satu dampak yang diakibatkan Covid-19 dalam aspek pendidikan adalah pembelajaran dari rumah.

Pembelajaran dari rumah dilaksanakan setelah diberlakukannya kebijakan Pembatasan Sosial Berskala Besar (PSBB). Kebijakan tersebut dilaksanakan dalam rangka mencegah penyebaran virus Covid-19 di Indonesia. Berdasarkan Surat Edaran (SE) Nomor 4 Tahun 2020 yang dikeluarkan oleh Menteri Pendidikan dan Kebudayaan bahwa proses belajar dari rumah dilakukan 
dengan ketentuan melalui pembelajaran dalam jaringan (daring)/ jarak jauh dilaksanakan untuk memberikan pengalaman belajar bermakna bagi siswa, tanpa terbebani tuntutan menuntaskan seluruh capaian kurikulum untuk kenaikan kelas maupun kelulusan.

Sekolah dalam menerapkan pembelajaran daring tidak semua siap. Misalnya sebuah sekolah dasar swasta di Kota Bandung, Jawa Barat. Salah satu guru tersebut yang bernama Irvan menyampaikan kepada wartawan Yulia Saputra yang melaporkan untuk BBC News Indonesia bahwa sekolahnya belum memiliki sistem belajar online. Jadi memanfaatkan WhatsApp saja untuk pembelajaran di kelas 1 sampai kelas 3, tapi untuk kelas 4 sampai 6 menggunakan Google Classroom.

Kendala selama pembelajaran daring berlangsung dirasakan oleh siswa, guru dan orang tua. Menurut berita dalam Kumparan New pada tanggal 15 Oktober 2020 mengenai "Pembelajaran Daring pada Siswa Sekolah Dasar (SD), Efektifkah?" yang diproduksi oleh Atikah Trisna Sari menyatakan bahwa pembelajaran tidak dapat berjalan dengan maksimal dan tujuan pendidikan tidak dapat tercapai sepenuhnya. Pendidik tidak dapat menjamin siswa telah menguasai berbagai materi yang disampaikan. Permasalahan pun timbul dalam pelaksanaan pembelajaran daring di $\mathrm{SD}$, di mana siswa SD belum mampu untuk memahami suatu materi sendiri sehingga orang tua harus turun tangan mengajari anak. Untuk orang tua yang memiliki waktu luang bukan suatu kendala yang berarti. Akan tetapi bagi orang tua yang bekerja atau yang tidak memiliki cukup waktu luang merupakan hal yang menyusahkan. Selain memikirkan pekerjaan ada tugas tambahan untuk mengajarkan kepada anak.

Kendala atau hambatan lainnya yang dipaparkan dalam berita Kompas.com pada 12 agustus 2020 dengan judul "Pendidikan Daring di Masa Covid-19" yang ditulis oleh Ana Shofiana Syatiri hambatan atau kendala yang dirasakan adalah tidak sedikit guru yang sekedar memberikan tugas kepada siswanya melalui aplikasi whatsaap group. Menurut Ana Shofiana metode tersebut dianggap memiliki banyak kelemahan karena aplikasi ini bukan 
medium untuk mendukung aktivitas pembelajaran. Untuk itu dibutuhkan medium dan bahan yang dapat menfasilitasi proses pembelajaran anak dalam memahami materi pembelajaran serta membantu orang tua ketika mengajarkan anak di rumah.

\section{Pembelajaran daring yang} diterapkan diseluruh jenjang sekolah dan biasanya menggunakan class room, zoom, google form, google meet, google form, whatsapp group, dan sebagainya. Hal tersebut menunjukkan penerapan kemajuan teknologi. Berdasarkan jurnal yang ditulis oleh Wahyu Aji Fatma Dewi degan judul "Dampak covid-19 terhadap imlementasi pembelajaran daring di sekolah dasar" bahwa dampak covid-19 terhadap implementasi pembelajaran daring di sekolah dasar dapat terlaksana dengan cukup baik apabila adanya kerjasama antara guru, siswa dan orang tua dalam belajar di rumah. Adanya kerjasama dan timbal balik antara guru, siswa dan orang tua yang menjadikan pembelajaran daring menjadi efektif.

Proses pembelajaran dapat diartikan sebagai sebuah kegiatan di mana terjadi penyampaian materi pembelajaran dari seorang tenaga pendidik kepada para siswa yang dimilikinya. Karenanya kegiatan pembelajaran ini sangat bergantung pada komponen-komponen yang ada di dalamnya. Dari sekian banyak komponen tersebut, maka yang paling utama adalah adanya siswa, tenaga pendidik, media pembelajaran, materi pembelajaran, serta adanya rencana pembelajaran (Sumantri, 2016).

Materi pembelajaran atau materi ajar atau bahan ajar adalah segala sesuatu yang hendak dipelajari dan dikuasi para siswa, baik berupa pengetahuan, keterampilan, maupun sikap melalui kegiatan pembelajaran (Sumantri, 2016). Bahan ajar yang merupakan komponen penting dalam proses pembelajaran hendaknya diolah dengan kreatif, agar terciptanya pembelajaran yang efektif. Tentunya dalam menciptakan pembelajaran yang efektif dibutuhkan suatu alat atau perangkat pembelajaran yang dapat memudahkan siswa dalam proses pembelajaran. Salah satu alat atau perangkat tersebut adalah modul. Modul merupakan bahan ajar yang digunakan siswa dalam mencapai tujuan pembelajaran. 
Berdasarkan jurnal yang ditulis oleh E. Nilasari, E. Djatmika, dan A. Santoso dengan judul "Pengaruh Penggunaan Modul Pembelajaran Kontekstual terhadap Hasil Belajar Siswa Kelas V Sekolah Dasar". Hasil penelitian tersebut menujukkan bahwa adanya pengaruh modul pembelajaran kontekstual terhadap hasil belajar siswa kelas $\mathrm{V}$ pada muatan tematik.

Berdasarkan jurnal artikel yang ditulis oleh A.Arnianti, D. M.Si dengan judul "Pengembangan Modul Berbasis Pengajaran dan Pembelajaran Kontekstual (contextual Teaching and Learning) pada mata pelajaran IPA Kelas V Sekolah Dasar". Dalam penelitain tersebut menunjukkan bahwa modul IPA berbasisi CTL yang sedang dikembangkan oleh peneliti memberikan efek potensial terhadap hasil belajar siswa.

Berdasarkan penelitian yang dilakukan oleh Mochamad Ali Imron dengan judul "Pengembangan Modul IPA Tema 2 (Selalu Berhemat Energi) berbasis Pendekatan Saintifik Kelas IV SD Kurikulum 2013. Hasil penelitian tersebut menunjukkan bahwa modul IPA tema 2 (Selalu Berhemat Energi) berbasis pendekatan saintifik layak digunakan sebagai bahan ajar tambahan dan efektif digunakan untuk siswa kelas IV sekolah dasar.

Dalam penelitian ini fokus penelitian diarahkan pada pelaksanaan penggunaan E-modul dalam pembelajaran daring muatan IPA di SD Muhammadiyah 5 Jakarta. Berdasarkan latar belakang yang telah dikemukakan di atas, maka dapat dirumuskan masalah dalam penelitian ini adalah "Bagaimana penggunaan E-modul dalam pembelajaran daring muatan IPA di SD Muhammadiyah 5 Jakarta?" Tujuan yang ingin dicapai dalam penelitian ini adalah menganalisis penggunaan E-modul dalam pembelajaran daring muatan IPA di SD Muhammadiyah 5 Jakarta.

Menurut Percival dan Ellington sumber belajar adalah sekumpulan bahan atau situasi yang diciptakan dengan sengaja dan dibuat agar memungkinkan siswa belajar sendiri secara individual (Evelin Siregar dan Hartini Nara, 2015). Adapun menurut Sudjana dan Rivai sumber belajar adalah segala daya yang dapat dimanfaatkan guna meemberi kemudahan kepada seseorang dalam 
belajarnya (Sudjana, 2007) Sedangkan menurut Andi Prastowo bahwa sumber belajar pada hakikatnya adalah segala sesuatu (benda, data, fakta, ide, orang, dan lain sebagainya) yang bisa menimbulkan proses belajar (Prastowo, 2018).

Berdasarkan pengertian di atas dapat didefinisikan bahwa sumber belajar adalah sekumpulan bahan yang dibuat untuk memberi kemudahan dalam belajar dan menimbulkan proses belajar secara individual.

\section{E-modul merupakan modul} yang bertransformasi menjadi bentuk elektronik. E-modul merupakan salah satu contoh dari pemanfaatan teknologi saat ini di bidang pendidikan. E-modul digunakan oleh pendidik dalam proses pembelajaran sebagai suatu kemudahan sebagaimana arti dari E-modul itu sendiri.

An electronic module can be interpreted as an electronic-based book which is written with the aim that students can study independently without or with the guidance of the teacher (Universitas Jambi, 2019). E- modul atau modul elektronik dapat diartikan sebagai buku berbasis elektronik yang ditulis dengan tujuan agar siswa dapat belajar secara mandiri tanpa atau dengan bimbingan guru.

E-modul dapat diartikan juga sebagai bentuk penyajian bahan belajar mandiri yang disusun secara sistematis, disajikan dalam bentuk elektronik, di mana setiap kegiatan pembelajaran di dalamnya dihubungkan dengan tautan atau link sebagai navigasi membuat peserta didik menjadi interaktif dengan program, dilengkapi dengan video, animasi untuk memperkaya pengalaman belajar.

Menurut Wijyanto modul elektronik atau E-modul merupakan tampilan informasi dalam format buku yang disajikan secara elektronik dengan menggunakan hard disk, disket, CD, atau flashdisk dan dapat dibaca dengan menggunakan komputer atau alat pembaca buku elektronik (Priyanthi, 2017).

Dari beberapa pengertian di atas dapat didefinisikan bahwa $E$ modul atau modul elektronik adalah buku yang ditulis secara sistematis 
serta disajikan dalam bentuk elektronik dengan tujuan untuk memudahkan siswa dan dapat belajar mandiri dengan menggunakan komputer atau alat pembaca elektronik.

Terdapat sepuluh karakteristik E-modul, yaitu yang pertama self instructional (siswa mampu membelajarkan diri sendiri, tidak tergantung pada pihak lain), self contained (seluruh materi pembelajaran terdapat dalam satu modul utuh), stand alone (modul yang dikembangkan tidak bergantung pada media lain), adaptif (mudah menyesuaikan dengan perkembangan ilmu dan teknologi), user friendly (akrab dengan pemakainya), konsisten dalam penggunaan font, spasi, dan tata letak. Karakteristik selanjutnya ialah disampaikan dengan menggunakan suatu media elektronik berbasis komputer. Memanfaatkan berbagai fungsi media elektronik sehingga disebut sebagai multimedia. Memanfaatkan berbagai filtur yang ada pada aplikasi software, dan karakteristik yang terakhir ialah perlu didesain secara cermat dengan memperhatikan prinsip pembelajaran.
Seiring adanya wabah covid-19 yang berkepanjangan, memberikan dampak yang besar dalam aspek kehidupan manusia. Salah satu aspek yang terknena dampak tersebut adalah pendidikan. Dalam aspek pendidikan, dampak yang diakibatkan adalah pembelajaran dari rumah.

Pembelajaran dari rumah dilakukan setelah diberlakukannya kebijakan Pembatasan Sosial Berskala Besar (PSBB). Berdasarkan Surat Edaran (SE) Nomor 4 Tahun 2020 yang dikeluarkan oleh Menteri Pendidikan dan Kebudayaan bahwa proses belajar dari rumah dilakukan dengan ketentuan melalui pembelajaran dalam jaringan (daring) atau jarak jauh dilaksanakan untuk memberikan pengalaman belajar bermakna bagi siswa, tanpa terbebani tuntutan menuntaskan seluruh capaian kurikulum untuk kenaikan kelas maupun kelulusan.

IImu Pengetahuan Alam (IPA) merupakan salah satu muatan pelajaran yang terdapat di sekolah dasar. Purnel's Concise Dictionary of Science, 1983 tercantum definisi IPA yaitu science the broad field of human knowledge, acquired by systematic observation and experiment, and 
explained by means of rules, laws, principles, theories and hypotheses. (Astawan dan Agustiana, 2020:3) IPA adalah pengetahuan manusia yang luas, yang diperoleh dengan cara pengamatan/observasi dan eksperimen yang sistematik, dan dijelaskan melalui aturan-atuan, hukum-hukum, prinsip-prinsip, teoriteori, dan hipotesis-hipotesis. Menurut Hungeford, Volk dan Ramsey IPA adalah (1) proses memperoleh informasi melalui metode empiris (empirical method), (2) informasi yang diperoleh melalui penyelidikan yang telah ditata secara logis dan sistematis, dan (3) suatu kombinasi proses berpikir kritis yang menghasilkan informasi yang dapat dipercaya dan valid. (Wedyawati dan Lisa, 2019:2) Sementara itu menurut Trowbridge dan Bybee IPA merupakan representasi dari suatu hubungan dinamis yang mencakup tiga faktor utama, yaitu "the extant body of scientific knowledge, the values of science, and methods and processes of science (Wedyawati, 2019).

Berdasarkan definisi di atas, dapat didefinisikan bahwa IPA adalah proses memperoleh informasi melalui penyelidikan yang logis dan sistematis meliputi pengamatan atau observasi dan eksperimen, dalam IPA terkandung tiga hal yaitu proses, prosedur, dan produk.

Terdapat banyak pandangan para tokoh mengenai anak SD, salah satunya John Locke. John Locke merupakan salah satu pelopor kaum environmental. Pendpaat yang terkenal dari John Locke ialah seperti tabula rasa tau kertas kosong. Pikiran seorang anak merupakan hasil dari pengalaman dan proses belajar. (Sumatri, 2016) Menurut Papalia dan Olds (1986) anak sekolah dasar termasuk ke dalam periode anak-anak madya (usia 6-12 tahun), ditandai dengan sebagian besar waktu yang ada digunakan untuk sekolah. Masa sekolah dasar dibagi menjadi dua fase, yaitu masa kelas rendah dan kelas tinggi. Sudah sepatutnya pembelajaran dilakukan lebih menarik perhatian siswa dan bermakna. Anak SD yang senang bermain menuntut seorang guru Sekolah Dasar (SD) untuk melaksankan proses pembelajaran yang menarik dan perhatian siswa. Selain dengan bermain siswa SD juga senang bergerak, siswa senang bekerja 
kelompok, dan senang merasakan atau melakukan/memperagakan sesuatu secara langsung.

Biasanya kelas V Sekolah Dasar (SD) berada dalam usia 10 tahun atau 11 tahun. Pada usia tersebut siswa mengalami perkembangan fisik, kognitif, sosioemosional, dan moral. Ditinjau dari teori kognitif Piget, siswa kelas V SD berada dalam tahap operasional konkret. Pada usia (6-12 tahun) sosial anak banyak dipengaruhi oleh orang dan lembaga, seperti keluarga, teman sebaya, sekolah, dan media lain seperti televisi.

\section{B. Metode Penelitian}

Penelitian ini menggunakan pendekatan kualitatif. Penelitian kualitatif digunakan agar data dan informasi yang diperoleh dapat lebih lengkap, mendalam serta bermakna sehingga dapat mencapai tujuan penelitian. Menurut Creswell, mendefinisikannya sebagai suatu pendekatan atau penelusuran untuk mengeksplorasi dan memahami suatu gejala sentral (Setiawan, 2010). Penelitian ini menggunakan metode fenomenologi. Fenomenologi merupakan salah satu metode kualitatif yang diperkenalkan oleh John Creswell.

Penelitian ini dilaksanakan di SD Muhammadiyah 5 Jakarta tahun ajaran 2020/2021. Pelaksanaan penelitian dimulai dari bulan Februari sampai April 2021. Tempat penelitian dilaksanakan di kelas V SD Muhammadiyah 5 Jakarta yang beralamat di Jl. Limau I-II-III Blok B No.3 RT.3/RW.3. Kelurahan Kramat Pela Kecamatan Kebayoran Baru Kota Jakarta Selatan DKI Jakarta. Subjek dalam penelitian ini adalah peserta didik kelas $\mathrm{V}$ sebanyak 24 siswa yang terdiri dari 12 siswa lakilaki dan 12 siswa perempuan.

Sumber data dalam penelitian ini adalah siswa-siswi kelas $\mathrm{V}$ imam hambali SD Muhammadiyah 5 Jakarta, wali kelas atau guru yang mengajar IPA kelas $\mathrm{V}$ SD Muhammadiyah 5 Jakarta, dan kepala sekolah SD Muhammadiyah 5 Jakarta sebagai penanggung jawab pelaksanaan pembelajaran. Prosedur pengumpulan data yang dilaksanakan pada penelitian ini yaitu dengan menggabungkan berbagai teknik pengumpulan data dan sumber data yang telah ada. Teknik-teknik yang digunakan dalam penelitian ini adalah 
wawancara, observasi dan dokumentasi.

Model analisis data yang digunakan adalah model Miles dan Huberman. Miles dan Huberman mengemukakan bahwa aktivitas dalam analisis data kualitatif dilakukan secara interaktif dan berlangsung secara terus menerus sampai tuntas, sehingga datanya sudah jenuh. Analisis data dilakukan pada saat pengumpualan data berlangsung, dan setelah selesai pengumpulan data dalam periode tertentu. Aktivitas dalam analisis data, yaitu data reduction, data display, dan conclusion drawing/verification. Setelah data diperoleh, tahap data yang dilakukan selanjutnya ialah pemeriksaan keabsahan data. Penelitian ini menggunakan teknik pemeriksaan keabsahan data yaitu peningkatan ketekunan dan triangulasi.

\section{Hasil Penelitian dan pembahasan}

Saat ini seluruh negara di dunia termasuk Indonesia sedang dilanda wabah covid-19. Di Indonesia wabah covid-19 tersebut semakin berkepanjangan dan memberikan dampak yang besar dalam aspek kehidupan manusia. Ekonomi, sosial, dan pendidikan tidak luput terkena dampak covid-19. Salah satu dampak yang diakibatkan covid-19 dalam aspek pendidikan adalah pembelajaran dari rumah.

Pembelajran dari rumah dikenal juga dengan pembelajaran online, pembelajaran dalam jaringan (daring), dan Belajar Dari Rumah (BDR). Pembelajaran daring tersebut diberlakukan pada setiap jenjang sekolah baik SD, SMP, SMA dan jenjang perguruan tinggi. Setiap sekolah berusaha dengan maksimal dalam menciptakan aktivitas pembelajaran yang memudahkan dan menyenangkan khususnya bagi siswa dalam memahami materi.

Beberapa sekolah menyiapkan dan menggunakan E-modul sebagai medium yang menfasilitasi proses pembelajaran anak dalam memahami materi pembelajaran serta membantu orang tua ketika mengajarkan anak di rumah. Salah satu sekolah yang menggunakan E-modul sebagai sumber belajar dalam pembelajaran daring adalah SD Muhammadiyah 5 Jakarta. SD Muhammadiyah 5 Jakarta merancang E-modul sebagai sumber 
belajar selama pembelajaran daring. E-modul tersebut bertujuan untuk mempermudah proses pembelajaran daring dan agar siswa tertarik menggunakan gadget dalam pembelajaran dengan tampilan warna, font, dan gambar yang cerah. SD Muhammadiyah 5 Jakarta mulai menggunakan E-modul pada awal tahun pelajaran 2020/2021 yaitu pada bulan juli 2020.

E-modul yang digunakan SD Muhammadiyah 5 Jakarta adalah Emodul berbasis web. E-modultersebut dapat diakses pada alamat website sekolah https://sdm5jakarta.sch.id/. Emodul yang digunakan dirancang khusus sebagai fasilitas belajar bagi siswa yang membantu selama pembelajaran daring dan dikategorikan sumber belajar yang direncanakan (by design). Pada kegiatan proses pembelajaran, $E$ modul membantu selama pembelajaran daring yaitu mempermudah dalam penyampaian materi, memiliki tampilan yang menarik, user friendly, dan E-modul dapat membantu memecahkan kesulitan siswa. E-modul yang digunakan memuat materi yang jelas bagi siswa, terdapatnya gambar, contoh simple, dan video sehingga mempermudah dalam penyampaian materi. Selain itu dengan adanya video dan edugame membuat $E$ modul semakin menarik dan menciptakan pembelajaran sesuai karakterstik anak SD yang suka bermain dan melatih kerja sama. Tampilan font, tata letak dan warna yang digunakan dalam E-modul menarik bagi siswa. E-modul yang digunakan user friendly, siswa mudah mengakses dan mudah untuk menggunakan E-modul tersebut dengan mengklik. Penggunaan Emodul membantu memecahkan kesulitan siswa selama pembelajaran daring. Siswa bisa membuka kembali materi yang telah dipelajari dengan mudah dan membantu siswa memahami materi dengan membaca kembali E-modul selain dari penjelasan guru.

Penggunaan E-modul meransang siswa dan memberi motivasi belajar kepada siswa. Penggunaan E-modul tersebut memberikan motivasi kepada siswa sehingga siswa rajin belajar dan rajin membaca. Hal tersebut menunjukkan salah satu keunggulan E-modul yaitu meningkatkan motivasi siswa. 
Penggunaan E-modul meransang siswa berpikir kritis dalam menjawab setiap soal evaluasi pada E-modul, ketika berdiskusi, dan menjawab pertanyaan dari guru. Penggunaan $E$ modul tersebut dalam pembelajaran daring mendapatkan respon positif dari siswa. Siswa merasa senang, semangat, dan tidak sabar menunggu materi E-modul berikutnya. Selain siswa penggunaan E-modul mendapatkan respon positif dari berbagai pihak yaitu orang tua, dinas, dan supervisi yayasan.

Penggunaan E-modul dalam pembelajaran daring muatan IPA membantu dalam tercapainya tujuan pembelajaran yaitu menambah wawasan siswa dan membantu siswa menjawab pertanyaan dari guru dengan tepat.

Ketika E-modul digunakan sebagai sumber belajar dalam pembelajaran daring tentunya memiliki hambatan. Hambatan yang dirasakan adalah provider atau jaringan yang down, server error atau website down, dan pendampingan orang tua. Akan tetapi hambatan tersebut dapat diminimalisir. Saat ini hambatan tersebut mengalami penurunan sekitar $50 \%$ berkurang.

\section{Kesimpulan}

Berdasarkan hasil penelitian yang telah dilakukan mengenai penggunaan E-modul dalam pembelajaran daring muatan IPA di kelas V SD Muhammadiyah 5 Jakarta dapat dipaparkan bahwa dalam kondisi saat ini dengan diberlakukannya pembelajaran dari rumah yang disebut juga dengan pembelajaran online atau pembelajaran dalam jaringan (daring), penggunaan E-modul dalam pembelajaran daring muatan IPA di kelas V SD Muhammadiyah 5 Jakarta sebagai sumber belajar efektif dan membantu siswa dalam belajar yaitu membantu selama pembelajaran daring, meransang siswa serta memberi motivasi belajar kepada siswa, dan tercapainya tujuan pembelajaran. Penggunaan E-modul dalam pembelajaran daring di SD Muhammadiyah 5 Jakarta digunakan sebagai penunjang dalam aktivitas pembelajaran daring. E-modul tersebut merupakan E-modul berbasis web yang memuat materi disertai gambar, video dan edugame yang membuat pembelajaran semakin menarik bagi siswa. Respon terhadap penggunaan E-modul dalam 
pembelajaran daring muatan IPA sebagai sumber belajar mendapatkan respon positif dari berbagai pihak yaitu siswa, orang tua dan pihak luar seperti sekolah lain. Ketika menggunakan Emodul dalam pembelajaran daring muatan IPA terdapat hambatan yang dirasakan baik oleh siswa, guru, dan orang tua yaitu seperti jaringan atau provider yang down, server error atau website down, dan pendampingan orang tua. Hambatan tersebut dapat diminimalisir dan saat ini hambatan mengalami penurunan sekitar $50 \%$.

\section{DAFTAR PUSTAKA}

Adnan, Evita dkk. 2016. Pengembangan Peserta Didik. Jakarta: UNJ Press.

Andriani, Rika dan Rasto. 2019. Motivasi Belajar sebagai Determinan Hasil Belajar Siswa. Jurnal Pendidikan Manajemen Perkantoran. Vol.4 No.1

Arnianti. 2017. Pengembangan Modul Berbasis Pengajaran dan Pembelajaran Kontekstual (Contextual Teaching and Learning) pada Mata Pelajaran IPA Kelas V Sekolah Dasar. Jurnal Penamas. Vol. 30 No.2.

Astawan, I Gusti dan I Gusti Ayu Tri Agustiana. 2020. Pendidikan IPA Sekolah Dasar. Bali: Nilacakra.
Balipost.com.Sistem

Daring Dikeluhkan Orangtua, Dewan Desak Kembali ke Sistem Tatap Muka.

https://www.balipost.com/news/2 020/08/10/141067/Sistem-

Daring-Dikeluhkan-

Orangtua,Dewan...html (Diakses tanggal 7 November 2020 pada pukul 16.48 WIB).

BBCNews. Virus Corona: Tak Semua Pengajar, Siswa Siap Terapkan 'sekolah di Rumah. https://www.bbc.com/indonesia/i ndonesia-51906763 (Diakses tanggal 7 November 2020 pada pukul 15.41 WIB).

Depdiknas. 2003. Undang-Undang Republik Indonesia No. 20 Tahun 2003 tentang Sistem Pendidikan Nasional.

Dewi, Wahyu Aji Fatma. 2020. Dampak Covid-19 Terhadap Implementasi Pembelajaran Daring di Sekolah Dasar. Jurnal Ilmu Pendidikan. Vol. 2 No. 1.

Djiwandono, Sri Esti Wuryani. 2006. Psikologi Pendidikan. Jakarta: PT. Gramedia Widiasarana Indonesia.

Herdiansyah, Haris. 2012. Metodologi Penelitian Kualitatif untuk IImuIImu Sosial. Jakarta: Salemba Humanika.

Imron, Mochamad Ali. 2018. Pengembangan Modul IPA Tema 2 (Selalu Berhemat Energi) 
Berbasis Pendekatan Saintifik Kelas IV SD Krikulum 2013. Skripsi.

Kemendikbud. 2016. Permendikbud No.021 tahun 2016 Tentang Standar Isi Pendidikan Dasar dan Menengah. Jakarta: Kemendikbud.

Kumparan.com. Pembelajaran Daring pada Siswa Sekolah Dasar (SD), Efektifkah?.

https://kumparan.com/atikahtrisn asari97/pembelajaran-daringpada-siswa-sekolah-dasar-sdefektifkah-1uOalcXxqUG

(Diakses tanggal 28 November 2020 pada pukul 05.53 WIB).

Menteri Pendidikan. 2020. Surat Edaran Nomor 4 tahun 2020 tentang Pelaksanaan Kebijakan Pendidikan dalam Masa Darurat Penyebaran covid 19.

Musfiqon. 2014. Metodologi Penelitian Pendidikan. Jakarta: PT. Prestasi Pustakarya.

Nilasari, E., E. Djatmika, dan A. Santoso. 2016. Pengaruh Penggunaan Modul Pembelajaran Kontekstual terhadap Hasil Belajar Siswa Kelas V Sekolah Dasar. Jurnal Pendidikan-Teori, Penelitian, dan Pengembangan.

Pohan, Albert Efendi. 2020. Konsep Pembelajaran Daring Berbasis Pendekatan Ilmiah. Grobogan: CV. Sarnu Untung.
Prastowo, Andi. 2018. Sumber Belajar dan Pusat Sumber Belajar Teori dan Aplikasinya di Sekolah/Madrasah. Depok: Prenadamedia Group.

Priyanthi, Kadek Aris dkk. 2017. Pengembangan E-modul Berbantuan Simulasi Berorientasi Pemecahan Masalah Pada Mata Pelajaran Komunikasi Data (Studi Kasus Siswa Kelas XI TKJ SMK Negeri 3 Singaraja. Jurnal Karmapati 6. No.6.

Serevina, Vina et al. 2018. Development of E-module Based on Problem Based Learning (PBL) on Heatand Temperature to ImproveStudent's Science Process Skills. TOJET (The Turkish Online Journal of Educational Technology). Vol.17.

Setiawan, Conny R.. 2010. Metode Penelitian Kualitatif. Jakarta: Grasindo.

Siregar, Evelin dan Hartini Nara. 2015. Teori Belajar dan Pembelajaran. Bogor: Ghalia Indonesia.

Soliki, Imam. 2018. Implementasi Emodul pada Program Studi Manajemen Informatika Universitas Bina Darma Berbasis Web Mobile. Jurnal Resti (Rekayasa Sistem dan Teknologi Informasi). Vol.2 No.2.

Sudjana, Nana dan Ahmad Rivai. 2007. Teknologi Pengajaran. Bandung: Sinar Baru Algesindo. 
Sugiyono. 2018. Metode Penelitian Kuantitatif, Kualitatif, dan $R \& D$. Bandung: Alfabeta.

Sumantri, Mohamad Syarif. 2016.

Strategi Pembelajaran: Teori dan

Praktik di Tingkat Pendidikan

Dasar. Jakarta: PT.

RajaGrafindoPersada.

Sunarya, Nita. 2018. Pengembangan

Modul Elektronik (E-modul)

Interaktif pada Mata Pelajaran

Kimia Kelas XI SMA. Jurnal Inovasi Teknologi Pendidikan.

Vol. 5.

Sutrisno. 2020. Meningkatkan Minat dan Hasil Belajar TIK Materi Topologi Jaringan dengan Media Pembelajaran. Malang: Ahlimedia Press.

Universitas Jambi. 2019. Development of E-module Based on Local Widson in Central Learning Model at Kindergartens in Jambi City. European Journal of Educational Research. Vol.8.

Wedyawati, Nelly dan Yasinta Lisa. 2019. Pembelajaran IPA di Sekolah Dasar. Sleman: Deepublish. 